\title{
SUPERSTITIONS IN ALGERIA
}

Notes Taken at a Series of Lectures Given in the Algiers University;

There are several forms of the Arab language peculiar to women, each having a name to distinguish it: (I) That which they use when no man is present, characterized principally by the free use of diminutives, viz: kharshif, the insertion of new words, and a strict avoidance of any word connected with magic and evil spirits, or that has any occult meaning, such as Khamsa. Children pick up much of this language, but with the boy it is quickly forgotten. (2) The language spoken to young children, composed of certain words and expressions, such as for instance the French word used in that way "dodo" (sleep). (3) That which they speak among themselves when they do not wish the men present to understand, formed through interpolation, transposition and mispronunciation.

The above three are in addition to the language which they have in common with the men.

Talismans are divided into two kinds, temporary and permanent. There are many of the former, as for instance, when a child is born, a plant is placed over its cradle to keep away the evil spirits. A knife, a piece of salt and a pail of water are put at the cradle head for the same purpose. Water is considered a specially good protector. A mother, on being asked how she could leave her tiny baby of two months alone, said, "But it is not alone, the pail of water is there !" It is thought lucky if one spills water on himself while drinking. Some of the talismans are writings from the Koran, which are placed in the pillow of the cradle or in the cap. A key is also put in the cap, or, in the case of the poor, a needle, iron being another thing supposed to have special preserving property. On hearing of any misfortune, touch iron! The so-called Fatima's hand is the talisman universally used, sometimes on the fronts of houses and sometimes on 
the caps. It may have five fingers, or even only two, in the case of ignorant people who do not know how to count. It is represented in a position indicating hostility towards the evil spirits, which is also one of the Moslem prayer postures. ${ }^{1}$ Hence the number 5 is thought lucky. If a mother is asked the age of her child, especially if it is being admired by the questioner, five will always come into her answer somewhere. The hand is sometimes put on the shoulder of an infant to ward off jealousy.

Then there is the tattoo talisman, a special mark used by the women.

The crescent is also universal. It is a sign of joy, because all the Moslem seasons of rejoicing begin at the new moon. It is the emblem of Stamboul. Many are the different changes in form it has undergone.

A talisman must always have sharp angles so as to pierce the evil eye, so we find at Biskra a cross is worn on the forehead. Perhaps it is an old Christian sign. In Turkey the crescent is kept to remind them of their past history.

There is another kind of tattoo among the Kabyles, used by the women out of coquettishness, but by the men to ward off ailments, i. e., on the forehead, to avert fever and headache, on the limbs to ward off rheumatism. It is also used to cover certain defects of nature.

There are also prevalent among Moslems paganistic practices, such as the piercing of the ears, which takes place when the infant is yet quite young, oblivious of the fact that the Prophet discountenanced earrings. This is to ward off $T a b a$, a savage and ferocious spirit, which they think pursues them. If all the children of a family die off, owing to disease or to hereditary causes, they say they have been overtaken by $T a b a$.

Certain metals are used by the Taleb, on which he writes pieces from the Koran, and gives to people to place over whatever part of their body is suffering.

1 Cf. Zwemer's "Influence of Animism in Islam." Chapter on Prayer. 
The following are some Moslem ideas on creation and childhood: In some parts women do not go out within four months of childbirth, lest the child should be affected physically or intellectually by anyone met in the street. During this period the mother follows a certain régime, i. e., making continually certain gestures, which are said to influence the young life. The hour of birth is thought to be of great importance, viz: If born at break of day, the child will be fortunate. If born at 8 o'clock (hour of work), it will lead a laborious life. If born at midday, it will rise above all circumstances, and its life will be permeated with sunshine. If born at sunset, it will be avaricious. If born at midnight, it will find favor with God, and its prayers will always be accepted by Him. The way it enters the world is also of importance, viz: If with closed hand, it will be avaricious. If born with open hand, it will be generous. If with the tongue out, it will be given to telling news. According to tradition, if anything good happens at the time of its birth, it will be fortunate through life and a blessing to the parents. If misfortune occurs at its birth, it is looked on as a curse. But according to some books a child is always a blessing.

Babies are supposed to inherit only the physical qualities of the mother, the rest is supposed to come from the father's side. Therefore when choosing a wife they say, "Consider well the character of the maternal uncles."

Each act of a child seems to have some significance: A baby boy smiles in its sleep, its angels are saying to it, "Thy father is dead, and thou wilt inherit all his property." A baby boy cries in its sleep, "Thy mother is dead," they say, "thy best friend is gone." A baby girl smiles in its sleep-the angels are saying to her, "Thy mother is dead, all her jewels are thine." A baby girl cries in its sleep, "Thy father is dead, thou hast lost thy best friend." If a child laughs in its mother's arms, it is said to be conversing with the angels. If it cries, a death is near (either itself or one of those around it). If some great 
crisis is at hand, such as in times of war, grave men stop in the street to watch the children at play, their actions determine the issue. Infants are supposed to be of equal intelligence to grown-up people, because they are supposed to be constantly conversing with the angels. Each child is said to represent a certain number of angels. It is thought they see and hear much more than we do, thus they are always removed from the vicinity of a dying person, for if they hear the death cry they will become dumb.

Some Moslem ideas on maladies are as follows: God sends illness like health, misfortune, etc. Maladies are caused by demons, they are also thought to be the result of magic. The evil eye, for instance, is a great reality, no one denies its existence: it is a universal fear, certain mothers in particular living in terror of it. Two of the ways of warding off the evil of it are: Blessing the Prophet, or stumbling over a stone, saying certain words, at which the influence from the evil eye enters the stone and cracks it.

Whooping-cough, they say, is caused by certain demons, which tickle the lungs. There are all sorts of remedies for this, such as giving the child snails and honey, also taking it to the gas works. This last would seem quite medical, but it is not so in reality, for they believe the fumes will drive the demons away. Then in cases where the cough is at its worst, they stretch the child out flat, and prepare an instrument with which to cut its throat. Having pretended to do this, they hold it up three times as an offering to the demon who they think is after it, thinking that he will then be satisfied and leave the child alone.

Convulsions, or "maladie des frères," is treated as follows: When a child is born, at the same time a little demon is brought into the world, whose birth takes place in the cupboard or the wall. ${ }^{2}$ If the child is prettier than 2 Cf. Zwemer's "Influence of Animism in Islam" (the Qarina). 
the demon, the latter gets jealous and causes the convulsions. The woman then goes round the court, and standing still in one corner converses with the demon, beseeching it to leave her little one in peace.

The demon specially feared for the children is called Taba; in order to deceive it all sorts of things are done. The following are instances: A black hen is kept in the room. Immediately the baby is born, it is driven far away from the house, and woe to him who picks it up, for the demon enters him instead of the child. Or a dog is kept in the room, who shares everything the mother has to eat. The demon enters the puppies. Or the child is sold. The woman to whom it has been sold comes to see it, it is told its mother has come, and she calls it her son, and they all act as if it were so.

Our science does not correspond with that of the Arabs as regards maladies or remedies. Jealousy in a child is considered and treated as an illness. At two years of age it is supposed to foresee the arrival of a little brother or sister, being in close intercourse with the angels, it sees them forming the object of its jealousy. This malady is treated in various ways, viz: An egg is boiled in quick lime, the shell taken off it is given to the child to eat. Or the child is placed on the doorstep with two eggs in its lap, other children come along and take them, the jealousy enters them, and the child is then supposed to be healed. Or it is given "l'eau des tombes" to drink (i. e., that water which they take to Marabouts) whilst the mother says some words to the effect that the heart of the child may become as cold as the dead body of the Marabout. Or it may be given water to drink in which a red hot iron has been cooled.

For hypochondria the child's headdress is taken off and heated, then the child is rubbed with it.

For a cold they take up a piece of the wool out of the carpet, put it in their mouth, and then rub it on the forehead of the patient. 
To cure snoring, they place a cat in a sack, then the sleeping infant is hit with it, and the snores enter the cat instead.

As a cure for crying, the child is taken to a Taleb, who gives it an amulet, or writes certain verses on a plate, the plate is then filled with water which the child has to drink. Or they take it to a Marabout. Another cure is to send all the children away from the house, then when all is quite quiet, a nut has to be cracked without anyone present being able to hear the slightest noise, if the nut does make the least sound in cracking the child will cry all night. Opium is administered to check crying from the very first hours of the little one's life. Another cure is to read a verse from the Koran, the word silent being repeated three times, upon which the infant is supposed to become instantly silent.

To cure backwardness in walking, eggs are broken on the child's legs, or it is put on the doorstep, figs and sugar being put on its knees. As in the case of jealousy, the one who takes them cures the child. Or the mother goes from house to house begging for flour to make a cake with, which when made is placed on the child's lap and then distributed to the poor.

For weak or short legs, at the time the call to prayer is heard on Friday, oxide of copper is put in water, a ring dipped in same is placed round the child's legs, and it is exhorted to "Get up and run, as the faithful run to prayer."

For backwardness in talking, the baby is made to drink the bath water of two turtle doves. At Blida the cure for this is as follows: At the time of the sacrifice seven of the sacrificed sheeps' tongues are procured, of which the child has to eat. Another cure is to give the child the tongues of certain birds.
Algiers.
I. LILIAS TROTTER. 